\title{
PEMANFAATAN ENTERPRISE ARCHITECTURE PLANNING UNTUK PERENCANAAN STRATEGIS SISTEM INFORMASI STMIK DIAN CIPTA CENDIKIA KOTABUMI
}

\author{
Sukatmi \\ Program Studi D3-Manajemen Informatika \\ AMIK DCC Bandar Lampung, \\ Jl. Cut Nyak Dien No. 65 Bandar Lampung, 0721- 250766, \\ sukatmi@dcc.ac.id
}

\begin{abstract}
ABSTRAK
Sekolah Tinggi Manajemen Informatika dan Komputer Dian Cipta Cendikia (STMIK DCC) Lampung merupakan salah satu perguruan tinggi komputer yang ada Lampung Utara. Sampai saat ini, dengan banyaknya sumber daya yang harus dikelola, STMIK DCC Lampung belum memiliki pengolahan data yang terintegrasi. Sumber daya dan data masih dikelola oleh masingmasing satuan kerja secara terpisah dengan mekanisme dan pola pengelolaan yang berbedabeda.
\end{abstract}

Untuk pengembangan sistem informasi terintegrasi diperlukan sebuah rencana strategi yang sesuai visi misi dan kebijakan organisasi. Oleh karena itu perlu dilakukan penelitian guna menghasilkan blue print rencana strategi sistem informasi STMIK DCC Lampung. Penelitian ini menggunakan metodologi Enterprise Architecture Planning (EAP).

Hasil akhir penelitian adalah cetak biru (blue print) atau arsitektur enterprise berupa rencana strategi sistem informasi STMIK DCC Lampung. Arsitektur enteprise tersebut diharapkan dapat dijadikan sebagai landasan untuk membangun Sistem Informasi Akademik yang terintegrasi di STMIK DCC Lampung. Pendefinisian enterprise ini menghasilkan 8 entitas, 8 sistem informasi dan 47 kandidat aplikasi

Kata kunci : Enterprise Architecture Planning, Arsitektur Data, Arsitektur Aplikasi, Arsitektur Teknologi, STMIK DCC Lampung. 


\begin{abstract}
Sekolah Tinggi Manajemen Informatika dan Komputer Dian Cipta Cendikia (STMIK DCC) Lampung is one of college computer that is Lampung North. Until now, with all the resources that must be managed, STMIK DCC Lampung do not have processing data that integrated. Resources and data are still managed by each working unit separately with mechanism and management pattern different..
\end{abstract}

To the development of information systems integrated required a plan strategy appropriate vision the mission and policy organization. By because it was necessary investigation to produce blue print of plans strategy STMIK DCC Lampung information system.

This research utilizing a methodology enterprise architecture planning (EAP). The final result research is blue prints or architecture enterprise strategy of the information systems STMIK DCC Lampung. Architecture enteprise is expected to be used as the runway to build academic information system integrated at STMIK DCC Lampung. Defining enterprise it produces 8 entity, 8 information systems and 47 candidates application.

Keywords : Enterprise Architecture Planning, Architecture Data, Architecture Application, Architecture Technology, STMIK DCC Lampung 


\section{PENDAHULUAN}

Perencanaan strategis sistem informasi diperlukan agar sebuah organisasi dapat mengenali target terbaik untuk melakukan proses bisnis dan penerapan sistem informasi manajemen serta menolong untuk memaksimalkan hasil dari investasi pada bidang teknologi informasi. Sebuah sistem informasi yang dibuat berdasarkan perancangan startegis sistem informasi yang baik, akan membantu sebuah organisasi dalam pengambilan keputusan untuk melakukan rencana bisnisnya dan merealisasikan pencapaian bisnisnya.. Perguruan tinggi sebagai intitusi yang bergerak dibidang pendidikan, dituntut untuk melakukan peningkatan mutu atau perbaikan secara berkesinambungan (continous improvement) yang memerlukan sistem manajemen tertentu untuk melakukannya seperti Total Quality Manajemen (TQM) dan manajemen bisnis total. Oleh karena itu adanya sistem di perguruan tinggi yang besar perlu dibuat suatu blueprint, dimana pada blueprint ini akan digambarkan seluruh proses bisnis yang ada diPerguruan Tinggi. Semua proses dalam perguruan tinggi akan di integrasikan dan dijadikan sebagai acuan untuk membuat aturan-aturan atau kebijakan yang ada dalam Perguruan Tinggi.

$\begin{array}{ccc}\text { Sekolah } & \text { Tinggi } & \text { Manajemen } \\ \text { Informatika dan } & \text { Komputer } & \text { Dian Cipta }\end{array}$

Cendikia (STMIK DCC) Lampung merupakan salah satu perguruan tinggi komputer yang ada di Kotabumi Lampung Utara. STMIK DCC Lampung berdiri pada tahun 2007 dengan 3 (tiga) program studi yaitu S1-Sistem Informasi, S1-Sistem Komputer dan D3-Teknik Komputer. Dalam perjalanannya STMIK DCC Lampung tumbuh menjadi perguruan tinggi komputer yang diminati oleh masyarakat Lampung Utara. Hal ini ditunjukkan oleh meningkatnya jumlah mahasiswa baru dari tahun ke tahun. Bertambahnya mahasiswa juga dibarengi dengan adanya peningkatan sarana prasarana, perbaikan manajemen dan peningkatan kompetensi sumber daya manusia baik dosen maupun tenaga administrasi. Mengingat pentingnya pengembangan suatu sistem informasi pada suatu perguruan tinggi, maka perguruan tinggi sebagai enterprise pelaksana perlu membuat cetak biru pengembangan sistem informasi sebagai acuan, panduan dan rencana yang jelas bagi pengembangan sistem informasi secara keseluruhan pada perguruan tinggi tersebut. Salah satu metodologi yang digunakan untuk merancang rencana strategis sistek informasi adalah Enterprise Architecture Planning (EAP). EAP merupakan proses pendefinisian arsitektur dalam penggunaan informasi untuk mendukung bisnis dan rencana untuk mengimplementasikan arsitektur tersebut. Misi yang ingin dicapai 
oleh EAP yaitu pengaksesan data yang lebih cepat kapanpun dan dimanapun diperlukan, sistem informasi dan IT yang digunakan fleksibel dengan perubahan serta mudah dikelola dan dipelihara, adanya keakurasian dan konsistensi data yang akan digunakan dalam semua unit organisasi, mempermudah penyebaran informasi dan data dalam enterprise, dan mengurangi biaya operasional atau pemanfaatan secara efektif biaya yang disediakan.

Khairul Imtihan dalam tulisannya yang berjudul Perencanaan Strategis Sistem Informasi Pendidikan Pada Sekolah Tinggi Manajemen Informatika dan Komputer Lombok membahas tentang pembangunan rencana strategi sistem informasi menggunakan metode kerangka kerja Jhon Ward dan Jhon Peppard dengan analisis Rantai Nilai (Value Chain) dan analisis McFarland Strategic Grid untuk menganalisis lingkungan internal sistem informasi pendidikan pada STMIK Lombok. Ruang lingkup penelitian meliputi operasional penerimaan mahasiswa baru, ujian masuk, penjadwalan kuliah, pengisian kartu rencana studi (KRS), perkuliahan, ujian tengah semester dan akhir semeter, penilaian, yudisium dan wisuda. Hasil akhir penelitian berupa perencanaan aplikasi portofolio yang dapat diimplementasikan sebagai strategi sistem informasi pendidikan pada STMIK Lombok. Perbedaan antara penelitian ini dengan penelitian yang dilakukan adalah: 1) metode yang digunakan yaitu penelitian ini menggunakan frame work Ward dan Peppard sedangkan penelitian yang dilakukan menggunakan metodologi Enterprise Architecture Planning (EAP); 2) Hasil akhir penelitian ini berupa perencanaan atau blueprint arsitektur aplikasi sedangkan hasil akhir dari penelitian yang dilakukan berupa blueprint rencana strategi sistem informasi yang terdiri arsitektur data, arsitektur aplikasi dan arsitektur teknologi.

\section{METODE PENELITIAN}

Metodologi yang digunakan dalam pembuatan rencana strategis sistem informasi di STMIK DCC Lampung ini adalah Enterprise Architecture Planning (EAP). EAP merupakan pendekatan yang modern untuk melakukan perencanaan terhadap kualitas data guna mencapai misi sistem informasi. EAP juga merupakan proses mendefinisikan sejumlah arsitektur yaitu: arsitektur data, arsitektur aplikasi, dan arsitektur teknologi dalam menggunakan informasi untuk mendukung bisnis. EAP memiliki keterkaitan dengan bagaimana menyelaraskan strategi bisnis dengan strategi TI dimana dalam pengembangannya strategi bisnis organisasi akan menjadi pijakan awal untuk menentukan strategi TI selanjutnya. EAP akan menyediakan peta dari enterprise dan 
merupakan jalur perencanaan untuk perubahan bisnis dan teknologi. [1]

Mengacu pada metode pengumpulan data dan kerangka kerja EAP maka penelitian akan dilakukan dengan tahapan sebagai berikut.

1) Melakukan studi pustaka dengan mempelajari literature yang relevan

2) Melakukan kegiatan observasi dan wawancara

3) Melakukan inisiasi perencanaan, yaitu mengidentifikasi aturanaturan yang ada di STMIK DCC Lampung diantaranya adalah visi, misi dan kebijakan manajemen. Hasil dari kegiatan ini adalah diperolehnya ruang lingkup EAP yang akan dibangun.

4) Melakukan tinjauan kondisi enterprise saat ini yang meliputi pemodelan proses bisnis dan sistem dan teknologi saat ini. Pada pemodelan proses bisnis akan dilakukan kegiatan:

1. mengidentifikasi dan mendokumentasikan struktur organisasi STMIK DCC Lampung;

2. mengidentifikasi dan mendefinisikan area bisnis utama yaitu area tri darma perguruan tinggi dengan menggunakan Model Rantai Nilai (Value Chain); 3) membuat matrik relasi antara fungsi bisnis dan unit organisasi yang ada di STMIK DCC Lampung guna mengetahui tanggung jawab dari masing-masing unit organisasi terhadap suatu fungsi bisnis. Pada tinjauan sistem dan teknologi saat ini akan dilakukan kegiatan mengidentifikasi dan mendokumentasikan sistem aplikasi dan platform teknologi yang digunakan STMIK DCC Lampung saat ini dan hasilnya berupa ringkasan yang disebut dengan Katalog Sumber Daya Informasi

(Information

Resource (atalog/IRC).

5) Melakukan tinjauan enterprise untuk masa depan yaitu kegiatan merancang arsitektur yang meliputi arsitektur data, arsitektur aplikasi dan arsitektur teknologi. Pada tahap merancang arsitektur data akan dilakukan kegiatan mengidentifikasi entitas data yang akan dibutuhkan oleh STMIK DCC Lampung kemudian dibuat relasi antar entitas dengan menggunakan teknik Entiry Relationship Diagram (ERD) dan dibuat matrik hubungan antara entitas data dan fungsi bisnis. 
Pada tahap merancang arsitektur aplikasi akan dilakukan kegiatan mendefinisikan aplikasi apa saja yang dibutuhkan oleh satuan organisasi yang ada STMIK DCC Lampung untuk mengelola data dan menyediakan informasi bagi satuan organisasi yang melakukan fungsi bisnis.

Pada tahap arsitektur teknologi akan dilakukan kegiatan mengidentifikasi dan mendefinisikan prinsip teknologi yang akan digunakan sebagai pendukung sistem informasi di STMIK DCC Lampung.[2] Pada tahap ini akan dilakukan penentuan platform teknologi yang akan digunakan dan disusun dalam konfigurasi konseptual teknologi atau rancangan jaringan teknologi.

6) Menyusun rencana implementasi, yaitu menyiapkan suatu rekomendasi untuk rencana implementasi.

Secara garis besar tahapan dan kerangka kerja EAP dalam penelitian dapat dilihat pada gambar 1 .

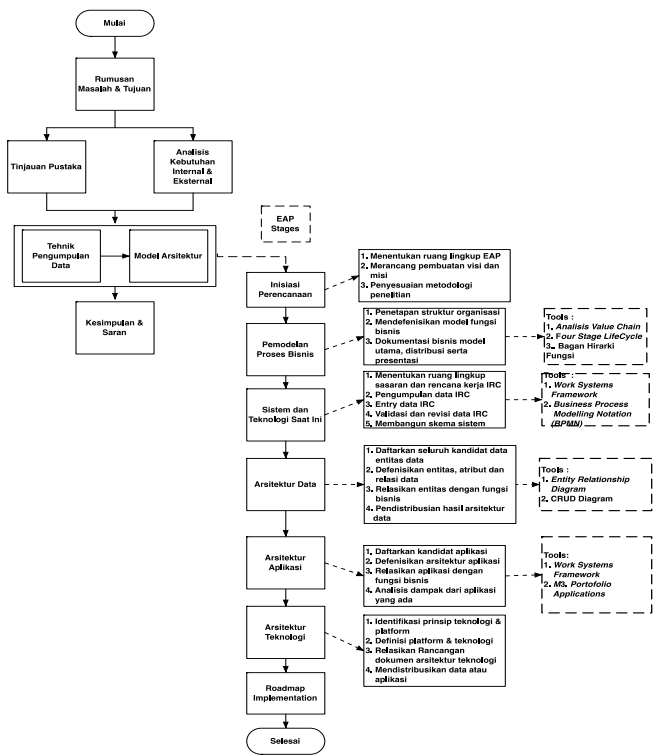

Gambar 1. Tahapan dan Kerangka Kerja

EAP dalam Penelitian

\section{HASIL DAN PEMBAHASAN}

\subsection{Analisa Rantai Nilai (Value Chain)}

Berdasarkan konsep rantai nilai Michael Porter, area fungsi utama untuk model pendidikan pada STMIK DCC Lampung dapat di kelompokkan ke dalam kegiatan utama (primary activities) dan kegiatan pendukung (support activities). Yang menjadi kegiatan utama pada STMIK DCC Lampung adalah penerimaan mahasiswa baru, operasional akademik serta pelepasan mahasiswa. Sedangkan kegiatan pendukung terdiri dari kegiatan yang berhubungan dengan bagian umum, sumber daya manusia, keuangan, penelitian dan pengabdian masyarakat serta pusat laboraturium komputer. 


\subsection{Tinjauan Sistem dan Teknologi}

\section{Saat Ini}

Berdasarkan kondisi yang ada saat ini bahwasanya STMIK DCC Lampung belum melakukan proses pengembangan sistem dan teknologi informasi yang terintegrasi guna mendukung proses bisnis khususnya kegiatan akademik pada STMIK DCC Lampung. Kesimpulan terkait dengan kondisi sistem dan teknologi saat ini adalah :

1. Belum adanya sistem dan teknologi yang terintergrasi untuk melaksanakan proses bisnis pada setiap bagian fungsi bisnis khususnya bagian akademik;

2. Penggunaan perangkat lunak aplikasi masih bersifat sebagai alat bantu pengolahan data (kata dan angka) seperti ms.word dan ms.excell;

\subsection{Perencanaan Arsitektur}

\subsubsection{Arsitektur Data}

Arsitektur data dibuat dalam bentuk ERDiagram. [3]

Berikut adalah Er-Diagram untuk Sistem Informasi Administrasi Akademik.

\begin{tabular}{|c|c|}
\hline No & 02 \\
\hline Unit Kerja & $\begin{array}{l}\text { Bagian Administrasi } \\
\text { Akademik } \\
\text { Kemahasiswaan } \\
\text { (BAAK) }\end{array}$ \\
\hline Kode Aplikasi & SI-02 \\
\hline Nama Aplikasi & $\begin{array}{l}\text { Sistem Informasi } \\
\text { Administrasi } \\
\text { Akademik }\end{array}$ \\
\hline $\begin{array}{l}\text { Nama Sub } \\
\text { Aplikasi }\end{array}$ & $\begin{array}{l}\text { Registrasi Ulang } \\
\text { Mahasiswa, Formulir } \\
\text { Rencana Studi, } \\
\text { Perubahan Formulir } \\
\text { Rencana Studi, } \\
\text { Penjadwalan Kuliah, } \\
\text { Dosen, Mahasiswa, } \\
\text { Administrasi } \\
\text { Perkuliahan, } \\
\text { Bimbingan Akademik, } \\
\text { Penjadwalan Ujian, } \\
\text { Pengolahan Nilai, } \\
\text { Manajemen Kurikulum, } \\
\text { Kalendar Akademik, } \\
\text { Kartu Hasil Studi, } \\
\text { Tugas Akhir, Cuti } \\
\text { Akademik, } \\
\text { Pindahan/Konversi, } \\
\text { Ujian Kompetensi dan } \\
\text { Pelaporan Akademik }\end{array}$ \\
\hline Penelitian & $\begin{array}{l}\text { Sistem ini dibuat } \\
\text { untuk digunakan } \\
\text { mengelola data } \\
\text { regristasi mahasiswa, } \\
\text { pembayaran kuliah, } \\
\text { administrasi } \\
\text { perkuliahan mulai } \\
\text { dari kurikulum, } \\
\text { jadwal perkuliahan, } \\
\text { data mahasiswa, data } \\
\text { dosen, ruang kuliah, } \\
\text { absensi perkuliahan, } \\
\text { tugas akhir, ujian } \\
\text { kompetensi, cuti } \\
\text { akademik, } \\
\text { pindahan/konversi, } \\
\text { sistem penilaian } \\
\text { sampai kegiatan } \\
\text { pelaporan akademik. }\end{array}$ \\
\hline
\end{tabular}




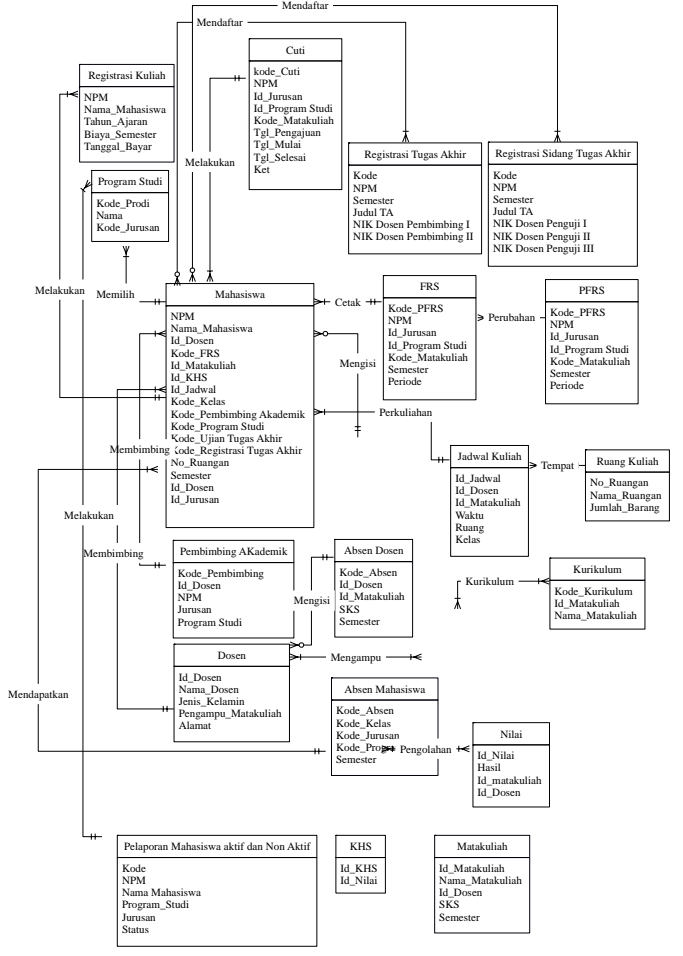

Gambar 2. ER-Diagram Aktifitas Utama (primary activity) Sistem Informasi Administrasi Akademik (SIAKAD) STMIK DCC Lampung

\subsubsection{Arsitektur Aplikasi}

Hasil pendefinisian terhadap arsitektur enterprise pada STMIK DCC Lampung memiliki 8 Entitas, 8 Sistem Informasi dan 47 usulan kandidat aplikasi yang nantinya bisa jadi acuan untuk pengembangan sistem informasi akademik.

Tabel 1. Arsitektur Aplikasi Sistem Informasi Administrasi Akademik (SIAKAD)

\subsubsection{Arsitektur Teknologi}

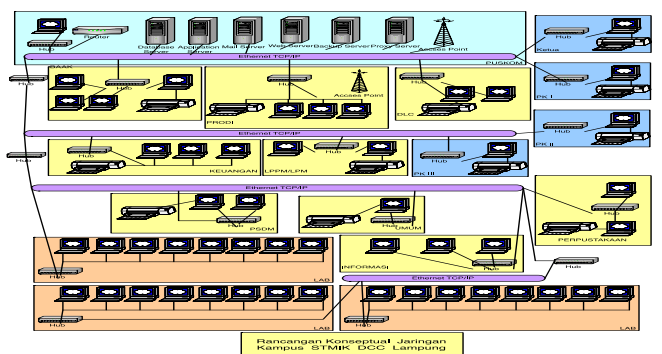

Gambar 3. Rancangan Konseptual Jaringan Kampus STMIK DCC Lampung

\section{PENUTUP}

Berdasarkan hasil penelitian dapat diambil beberapa kesimpulan sebagai berikut :

1. Dari analisa terhadap proses bisnis dan kebijakan yang ada di STMIK DCC Lampung diperoleh data guna penyusunan rencana strategi sistem informasi. Adapun data yang diperoleh dari kegiatan ini meliputi gambaran umum organisasi dan visi misi, kebijakan institusi tentang pengembangan sistem informasi, stakeholder institusi, teknologi yang saat ini digunakan untuk mendukung proses bisnis, unit pengelolan sistem informasi, proses bisnis yang ada disetiap stakeholder dan kebutuhan data dan informasi untuk pihak internal dan eksternal institusi.

2. Menghasilkan blueprint/cetak biru rencana strategi sistem informasi STMIK DCC Lampung.

\section{DAFTAR PUSTAKA}

[1] Ferly Ardhy, 2015, Enterprise Architecture Planning (Eap) Dalam Penyusunan Perancangan Sistem 
Informasi Akademik Yang

Terintegrasi, Jurnal Informasi Dan

[2] Rahmatullah, Sidik. "Rancang Bangun Sistem Ujian Berbasis Komputer Pada Smk Bhakti Utama Bandar Lampung." Jurnal Informasi Dan Komputer 6.1 (2018).

[3]Heriadi, Agustono, Mohammad Suyanto, And Sudarmawan Sudarmawan "Perencanaan Strategis Sistem Informasi Stmik Cahaya Surya Kediri." Creative Information Technology Journal 1.1 (2013): 1524.

[4] Jogianto H.M., Analisis Dan Desain (Sistem Informasi : Pemdekatan Terstruktur Developing A Blue Print For Data, Application And Technology, Jonh Willey \& Sons, New York

[5] Ward, J. And Peppard, J. (2002). Strategic Planning For Information Systems, $3^{\text {rd }}$ ed., John Wiley \& Sons, 2002. 